\title{
Design and Optimized of Solar PV System a Case Study of KIOT Administration Offices
}

\author{
Degarege Anteneh ${ }^{1, *}$, Birhanu Alene ${ }^{1,2}$ \\ ${ }^{1}$ Department of Electrical \& Computer Engineering, Debre Berhan University, Debre Berhan, Ethiopia \\ ${ }^{2}$ Department of Electrical \& Computer Engineering, Bahir Dar University, Bahir Dar, Ethiopia
}

Email address:

dagim3763@gmail.com (D. Anteneh), birhanualene1023@gmail.com(B. Alene)

${ }^{*}$ Corresponding author

\section{To cite this article:}

Degarege Anteneh, Birhanu Alene. Design and Optimized of Solar PV System a Case Study of KIOT Administration Offices. Journal of Electrical and Electronic Engineering. Vol. 8, No. 1, 2020, pp. 27-35. doi: 10.11648/j.jeee.20200801.15

Received: August 2, 2019; Accepted: November 12, 2019; Published: March 2, 2020

\begin{abstract}
Design and optimized of solar PV system is a leading trend in modern energy management of distribution system. In modern or currently most of the life, customers take in energy from different sources like, sunlight, wind, diesel, biomass, even batteries and from main grid of electric power and facilitate not only its conversion into electric energy, but also the demand management, storage and generation association with the system's output. In recently distributions generations (micro grid) implementations combine loads with sources, allow for intentional islanding and try to use the available waste heat. These solutions rely on complex communication and control, and are dependent on key components and require extensive site engineering. This paper focuses on the design, optimization and simulation of $48-\mathrm{V}$ rated stand-alone solar PV using HOMER software that is suppling primarily by photovoltaic (PV) panels and using battery and diesel for comparison, but which also has the capability to tie in to a main electrical grid. A system of this size should be able to supply power for KIOT administration office buildings. The most important objectives of this paper are the selections of an appropriate PV array, the selection or design of a charge controller and the design of the system's renewable energy converter.
\end{abstract}

Keywords: Design of PV, HOMER, Charge Controller, Battery Sizing, Feasibility Study, Inverter

\section{Introduction}

One of the best ways to get power to remote, off-grid locations and reliable electric power in grid connected system, whether in developed or developing countries is through Solar Home System (SHS). The system includes Solar PV, battery, solar charge controller and inverter. In most cases consumers consume solar energy at evening hours. So, solar energy shall be stored into batteries [1]. A solar charge controller is similar to the voltage regulator. It regulates the voltage and current that is coming from the solar panels and going to the battery. Most of the batteries are fully charged at 14 to 14.5 volts. On the other hand, battery's life time drastically reduces due to the discharge over the level of $70 \%-80 \%$, at this discharge level the battery voltage normally goes down to 11.5 volts. Each battery has a certain limit of capacity. Battery lifetime reduces drastically due to overcharging and deep discharging. As battery is a very expensive component of a Solar Home System, it is necessary to protect the batteries from being over charged or deeply discharged. In this case charge controller plays a vital role to protect the battery. A series charge controller disables further current flow into batteries when they are full. A shunt charge controller diverts excess electricity to an auxiliary or "shunt" load, such as an electric water heater, when batteries are full. Since the industrial revolution, human activities have constantly changed the natural composition of earth's atmosphere. Concentrations of trace atmospheric gases, nowadays termed "greenhouse gases" are increasing at an alarming rate [2]. The consumption of fossil fuels, conversion of forests to agricultural land and the emission of industrial chemicals are principal contribution factor to air pollution. Under normal atmospheric conditions, energy from the sun controls Earth's whether and climate pattern. Heating of Earth's surface from the sun radiates energy back to the space. This will result the greenhouse effect or global warming. Global and national scenarios of primary and in 
particular electrical energy consumption for the coming decades basically all predict a strong increase in technical utilization of renewable energy (RE). A significant increase in the use of RE satisfies the requirements of climate protection and allows suitable growth in energy consumption for newly developed and developing countries. At the same time, the aims to decrease the share of fossil primary energies in the medium and long time, and has the potential to reduce the share of nuclear energy to zero. However, to achieve this goal all RE technologies (hydro power, wind power, biomass, geothermal heat and solar irradiation) have to be mobilized in a balanced way and in coordinated time sequence, which is according to their economic market relevance and their technical potential. Among RE, solar irradiation will in the long term have to become the main contributor to a global renewable energy supply because of its unlimited potential. Photovoltaic (PV) is favored by its flexibility with respect to size and fields of application, its long life-time and low required maintenance. PV system is a device that mainly used to convert solar energy (which is the utilization of the radiant energy from the sun) to the electricity [3]. Solar power is often used interchangeably with solar energy but refer more specifically to the conversion of sunlight into electricity. Presented of PV technology that used to convert solar energy to the electric energy was acknowledge and used in many countries around the world nowadays.

Photovoltaic (PV) is the technology used to convert the energy directly from the sunlight into electricity by using the solar cell. The photon from the sunlight knock electron into higher energy which will produce electricity. A typical photovoltaic cell produces less than 3 watts at approximately 0.5 volt dc, cells must be connected in series-parallel configurations to produce enough power for high power applications. The electricity produce are in direct current which can be used to power equipment or to recharge battery. The first application of photovoltaic was used to power up the orbiting satellites and space shuttle. Nowadays, photovoltaic is important in grid-connection generation which required an inverter to convert DC current to $\mathrm{AC}$ current [4].

Table 1. Factor that can attract people interested using PV system.

\begin{tabular}{ll}
\hline Advantage of using PV & Disadvantage of using PV \\
\hline $\begin{array}{l}\text { Have a warranty until } 20 \text { years and more. and System is very durable and not } \\
\text { easily damage }\end{array}$ & The production of electricity is uneven throughout the day. \\
$\begin{array}{l}\text { Solar energy production is quite } \\
\text { Pay off point (which mean no need pay monthly bill) Even there are many } \\
\text { advantages of PV system. }\end{array}$ & System does not produce electricity at the night or when it is overcast. \\
\hline
\end{tabular}

This research is involved to design the software to make the calculation to choose the solar panel and inverter become easier. The software must be based on the case study to implement the solar panel to the KIOT administration offices.

To choose the suitable solar panel and inverter that can be implemented to KIOT administration offices, the data of the power consumption must be get first before can design the suitable software to make the calculation to find and choose the suitable inverter and solar panel that can be implemented to KIOT administration offices.

\section{Solar Radiation}

Based on different researches, $51 \%$ of the total solar energy reaches at ground, $6 \%$ is reflected by the atmosphere, $10 \%$ is reflected by the clouds, $4 \%$ is reflected from the earth's surface, $16 \%$ is absorbed by the atmosphere and the other $3 \%$ is absorbed by the clouds as shown in the figure below [5-6].

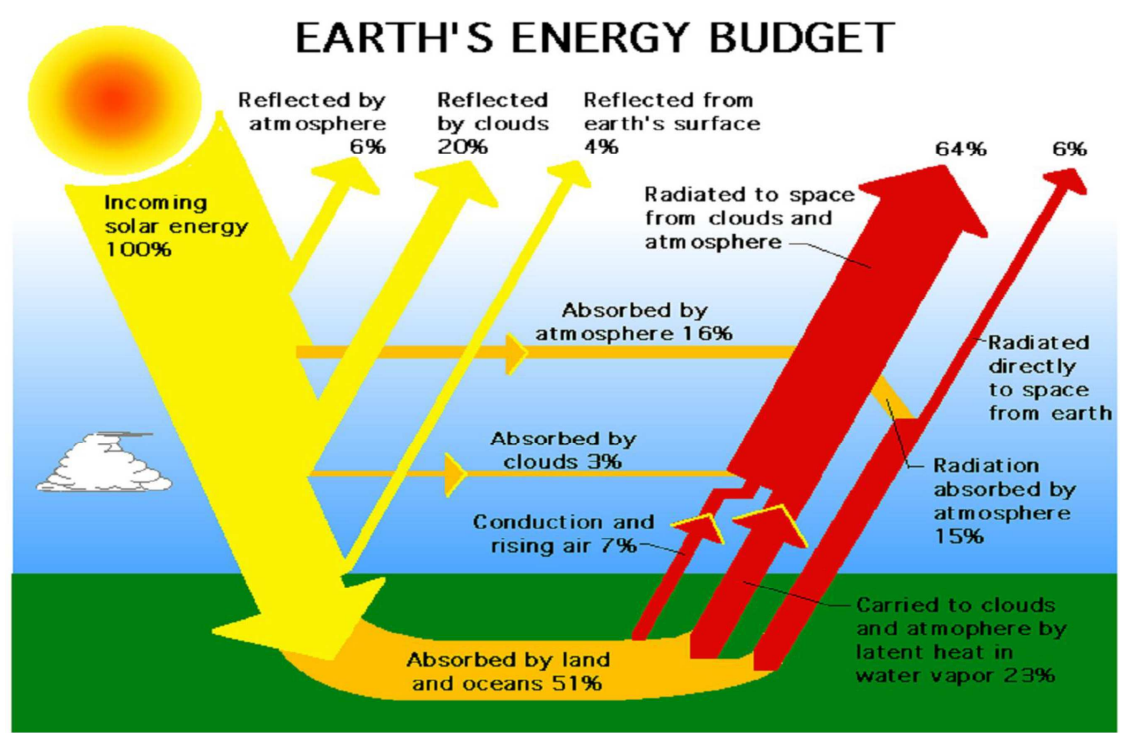

Figure 1. Total sun radiation and earth energy budget. 
Solar radiation is an electromagnetic wave emitted by the sun's surface that originates in the bulk of the sun where fusion reactions convert hydrogen atoms into helium. Every second $3.89 \times 10^{26} \mathrm{~J}$ of nuclear energy is released by the sun's core. This nuclear energy flux is rapidly converted into thermal energy and transported toward the surface of the star where it is released in the form of electromagnetic radiation. The power density emitted by the sun is of the order of $64 \mathrm{MW} / \mathrm{m}^{2}$ of which approximately $1370 \mathrm{~W} / \mathrm{m}^{2}$ reach the top of the Earth's atmosphere with no significant absorption in the space [8]. The latter quantity is called the solar constant. The spectral range of the solar radiation is very large and encompasses nano metric wavelengths of gamma- and $\mathrm{x}$ rays through metric wavelengths of radio waves.

\subsection{Cell, Module \& Array}

Since an individual cell can be produces $0.5 \mathrm{~V}$ or $0.8 \mathrm{~V}$, it is a rare application for which just a single cell for any use. Instead, the basic building block for PV applications is a module consisting of a number of pre-wired cells in series, all encased in tough weather-resistant packages. A typical module has 36 cells in series and is often designated as a "12$\mathrm{V}$ module" even though it is capable of delivering much higher voltages than that. Some $12-\mathrm{V}$ modules have only 33 cells, which, as will be seen later may be desirable in certain very simple battery charging systems. Large 72-cell modules are now quite common, some of which have all of the cells wired in series, in which case they are referred to as $24-\mathrm{V}$ modules. Some 72-cell modules can be field-wired to act either as $24-\mathrm{V}$ modules with all 72 cells in series or as $12-\mathrm{V}$ modules with two parallel strings having 36 series cells in each.

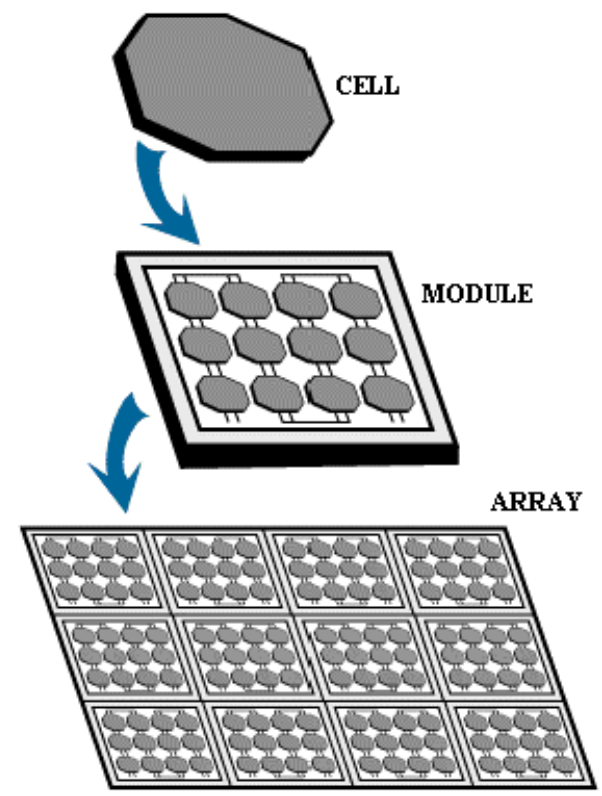

Figure 2. Formation of cell, module (combination of cells) \& array (combination of modules) of $P V$.

Multiple modules, in turn, can be wired in series to increase voltage and in parallel to increase current, the product of which is power. An important element in PV system design is deciding how many modules should be connected in series and how many in parallel to deliver whatever energy is needed. Such combinations of modules are referred to as an array.

From cells to modules when photovoltaic are wired in series, they all carry the same current and at any given current their voltage adds. From modules to array modules can be wired in series to increase voltage, and in parallel to increase current. Arrays are made up of some combination of series and parallel modules to increase power.

\subsection{Working Principle of PV System}

Solar or photovoltaic (PV), cells are electronic devices that essentially convert the solar energy of sunlight into electric energy or electricity. The physics of solar cells is based on the same semiconductor principles as diodes and transistors. Solar cells convert energy as long as there is sunlight. In the evenings and during cloudy conditions, the conversion process diminishes. It stops completely at dusk and resume at dawn. Solar cells do not store electricity, but batteries can be used to store the energy [9-10].

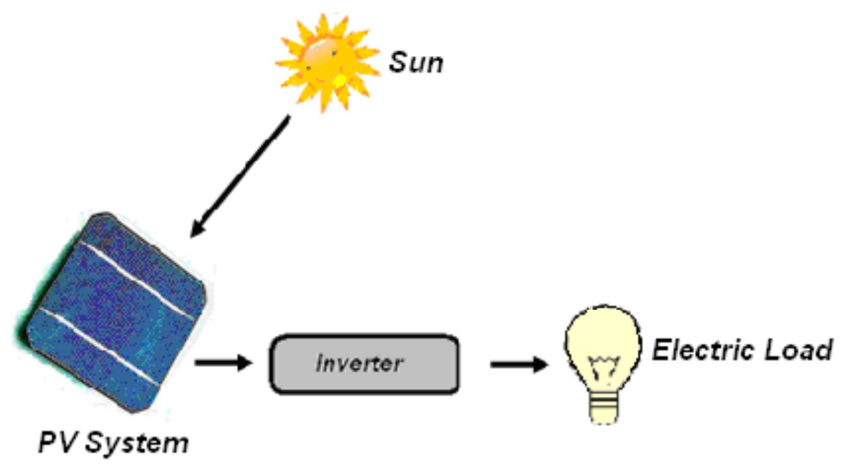

Figure 3. Light energy converted to electricity through PV system.

The most basic power conversion unit of a photovoltaic (PV) system is the solar cell. As shown in figure 3 sunlight strikes a PV cell and a direct current (D.C.) is generated. An inverter inverts the D.C. to an alternating Current (A.C.) and by connecting the electric load to the output terminals, the current can be utilized [11-12].

\section{Data Collection}

There are different loads and their rating at KIOT administration building.

1. Fluorescent lamps the rating value are $30 \mathrm{w}, 110-220 \mathrm{v}$ $\mathrm{AC}$ and 50/60 HZ.

2. DELL and HP computer the rating value are running value $60-250 \mathrm{w}$ and sleep and standby $1-6 \mathrm{w}, 110-220 \mathrm{v}$ $\mathrm{AC}$ and 50/60 HZ.

3. Brother printer the rating value $350 \mathrm{w}, 110-220 \mathrm{v}$ AC and $50 / 60 \mathrm{~Hz}$.

4. Canon 2318 photo copy machine the rating value 
$650 \mathrm{w}, 220-240 \mathrm{v}$ and $50 / 60 \mathrm{~Hz}$

5. Scanner the rating value $25 \mathrm{w}, 110-240 \mathrm{v}$ AC and sleep and standby $0.5 \mathrm{w}$ and $50 / 60 \mathrm{~Hz}$.

6. Brother photo copy machine rating value $445 \mathrm{w}, 110-$ 240v AC standby 55w and sleep $1 \mathrm{w}$.

7. Fax machines the rating value $120 \mathrm{w}, 110-240 \mathrm{vAC}$ and $50 / 60 \mathrm{~Hz}$

8. Color printer the rating value $32 \mathrm{w}, 110-240 \mathrm{v}$ AC and sleep and standby $3 \mathrm{w}$ and 50/60.

9. Switcher the rating value $370 \mathrm{w}, 220-240 \mathrm{v} A C$ and $50 / 60 \mathrm{~Hz}$.

10. Laptop computer the rating value $15-45 \mathrm{w}, 110-240 \mathrm{v}$ $\mathrm{AC}$, sleep and standby 1-6w.

\subsection{Estimate the Total Loads of KIOT Administration Building}

First, a load chart is developing based on the load and consumption of energy. Different appliance, their wattage, number of appliances and duration of usage are required to develop the load chart. The load chart is prepared by multiplying the number of appliances with wattage of each appliance to get maximum watts. This is multiplied with number of hours of usage to get watt hours. For different appliances the maximum watts, average watts and total watt hours are aggregated individually for calculation purpose.

1. Hours per day used is the number of hours each appliance used per day is listed in Hrs. actual time of load operation, must be considered here.

2. Energy per day is the amount of energy each appliance requires per day is determined by multiplying each appliance's wattage by the number of hours used per day.

3. Total energy demand per day. The sum of the quantities in the last column determines the total energy demand required by the appliances per day.

Table 2. The total load in KIOT building and the amount of watt.

\begin{tabular}{|c|c|c|c|c|c|}
\hline Appliance & Quantity & $\begin{array}{l}\text { Wattage of } \\
\text { appliance }(W)\end{array}$ & $\begin{array}{l}\text { Operational hours } \\
\text { (Hrs) }\end{array}$ & $\begin{array}{l}\text { Total amount of } \\
\text { power }(W)\end{array}$ & $\begin{array}{l}\text { Total amount of energy } \\
\text { (WH) }\end{array}$ \\
\hline Fluorescent la & 150 & 30 & 2 & 4500 & 9000 \\
\hline Desktop dell & 30 & 275 & 6 & 8250 & 49500 \\
\hline Brother printer & 3 & 350 & 0.5 & 1050 & 525 \\
\hline Canon photocopy & 3 & 650 & 1 & 1950 & 1950 \\
\hline Scanner & 3 & 25.5 & 0.25 & 76.5 & 19.125 \\
\hline Color printer & 2 & 32 & 0.25 & 64 & 16 \\
\hline Switcher & 2 & 370 & 8 & 740 & 5920 \\
\hline photo copy & 1 & 501 & 0.5 & 501 & 250.5 \\
\hline Total & & & & 17551.5 & 68110.625 \\
\hline
\end{tabular}

Table 3. Types of loads in KIOT administration offices, in hours demand for KIOT.

\begin{tabular}{ll}
\hline HOURS & LOADS $(\mathbf{K W})$ \\
\hline 0 & 0.5 \\
1 & 0.5 \\
2 & 0.5 \\
3 & 0.5 \\
4 & 0.5 \\
5 & 0.5 \\
6 & 0.5 \\
7 & 0.5 \\
8 & 6 \\
9 & 7 \\
10 & 9 \\
11 & 7 \\
12 & 2.11 \\
13 & 5.5 \\
14 & 7.5 \\
15 & 8 \\
16 & 6.5 \\
17 & 2.5 \\
18 & 0.5 \\
19 & 0.5 \\
20 & 0.5 \\
21 & 0.5 \\
22 & 0.5 \\
23 & 0.5 \\
Total (KWH) & 68.11 \\
\hline
\end{tabular}

Peak sun hours at optimum tilt is obtained from solar radiation data for the design location and array tilt for an average day. Annual average Peak sun hours at Latitude 10.986 degrees north for Kombolcha is 5.89 hours. 


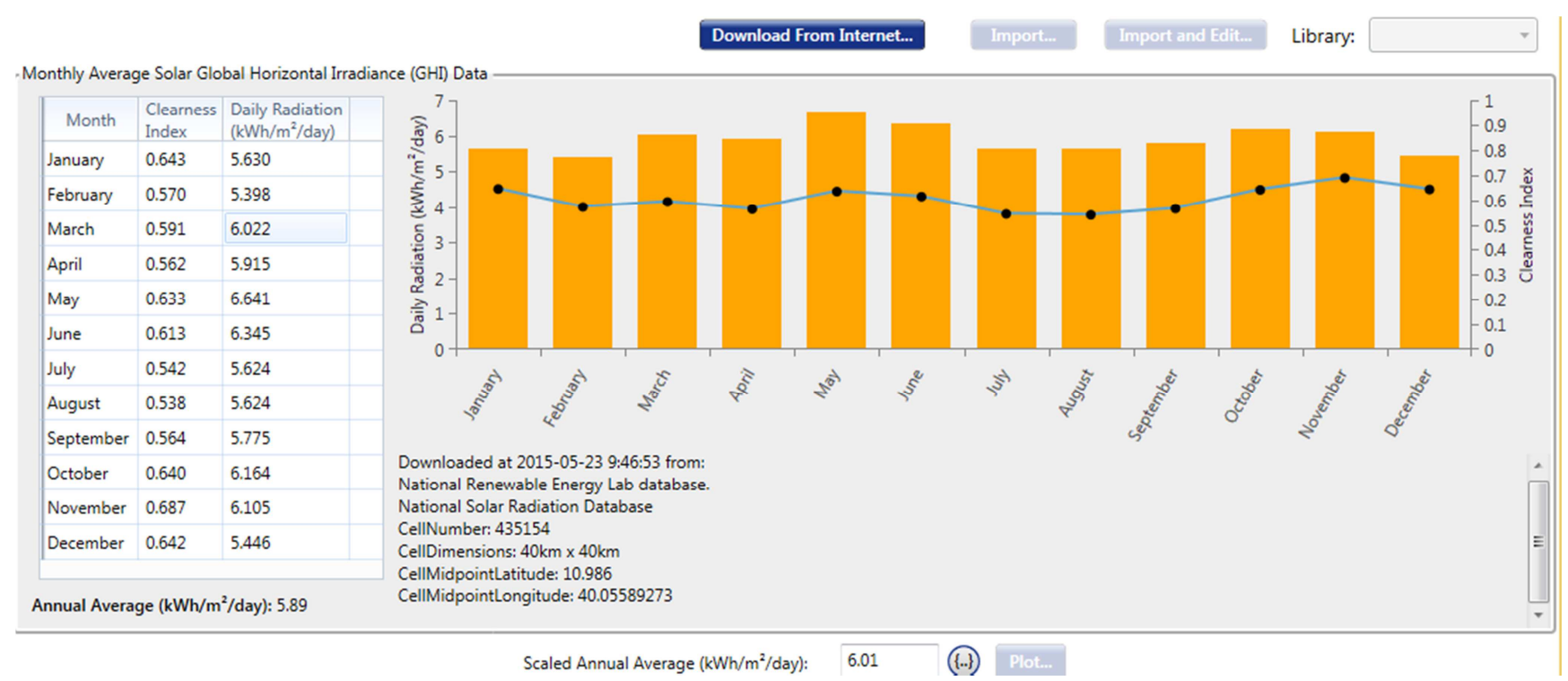

Figure 4. Monthly solar radiation of Kombolcha.

\subsection{Solar PV System Design Calculation for KIOT Administration Building}

In this part, determine the number of inverters, charge controller, battery, solar PV modules and series and parallel connection of battery and determine the rating value of each equipment based on the collected data (electrical loads). The figure shows below the block diagram of the connection procedures of KIOT administration offices.

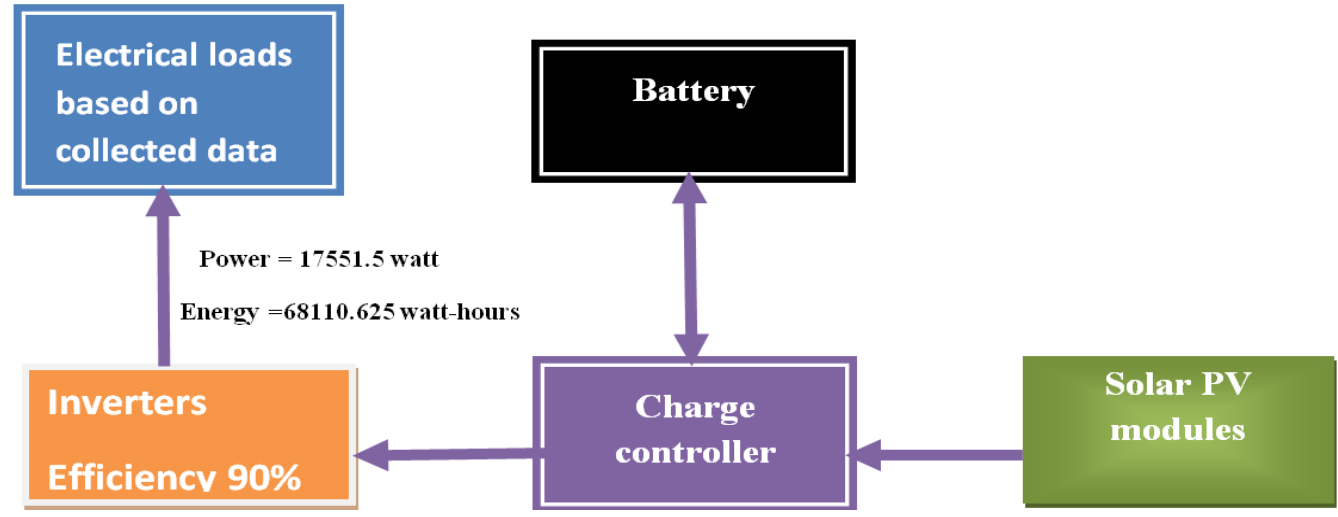

Figure 5. Block diagram of the connection procedures.

\subsubsection{Mounting Structure}

The PV module should be designed in such a way that it can withstand rain, hail, wind and other adverse conditions. Tilting angle optimally varies the efficiency of the solar PV module so; the mounting structure also serves as a PV module tilting structure which tilts the PV arrays at an angle determined by the latitude of the site location, to maximize the solar insulations falling on the panels. The optimum tilt angle required to maximize the solar insulations changes as the position of the sun varies every month. Similarly, shading has a significant effect on PV generation. Partial shading can reduce the system production up to $90 \%$. Thus, it is essential that the PV arrays to be installed at a suitable location without any difficulties.

The angle formed between the plane of the equator and a line drawn from the center of the sun to the center of the earth is called the solar declination, $\delta$. It varies between the extremes of $\pm 23.45^{\circ}$, and a simple sinusoidal relationship that assumes a 365-day year and which puts the spring equinox on day $\mathrm{n}=81$ provides a very good approximation.

$$
\delta=23.45 \sin [360 \div 365(n-81)]
$$

Then, the design month is May.

$\mathrm{n}=121$.

$$
\begin{gathered}
\delta=23.45 \sin [360 \div 365(121-81)] \\
\delta=14.9
\end{gathered}
$$

Then, the altitude angle of the sun

$$
\beta N=90^{\circ}-L+\delta=90-10.986+14.9=64.114
$$

The tilt angle that would make the sunray perpendicular to the module at noon would therefore be Tilt angle $=90^{\circ}-$ $\beta N=90-64.114=25.886$ 


\subsubsection{Cost Estimation of KIOT Administration Building}

PV panels are the most expensive part of a solar electric system; as such, they are sometimes targets for theft.
Vandalism can also be a problem. For larger loads, their high capital cost can render them a less preferable option if grid extensions or fuel for generators are readily available.

Table 4. Cost considerations of PV system design of KIOT.

\begin{tabular}{llll}
\hline Components & Cost & Total cost $\mathbf{( \$ )}$ & Percentage of total cost \\
\hline PV module & $0.6(\$ / \mathrm{w})$ & 11352 & 38.08 \\
Battery & $\$ 345$ & 9660 & 32.4 \\
Inverter & $\$ 200 / \mathrm{KW}$ & 4000 & 13.42 \\
Charge controller & 750.75 & 3753.75 & 12.6 \\
Mounting & & 500 & 1.7 \\
Labor & & 100 & 0.3 \\
Miscellaneous & & 200 & 0.7 \\
Cables & & 150 & 0.5 \\
Maintenance & 100 & 0.3 \\
Total & $\$ 29815.75$ & $100 \%$ \\
\hline
\end{tabular}

Regular maintenance on batteries is essential; they should be checked every month, with the electrolyte level replenished as needed. Properly maintained, batteries should last several years before needing replacement.

\subsubsection{Electrical Loads}

The average hourly electrical loads for each month of the year for the KIOT administration building are inputs of HOMER software. The system immediately graphs the load and calculates parameters as shown in figure 6 below.

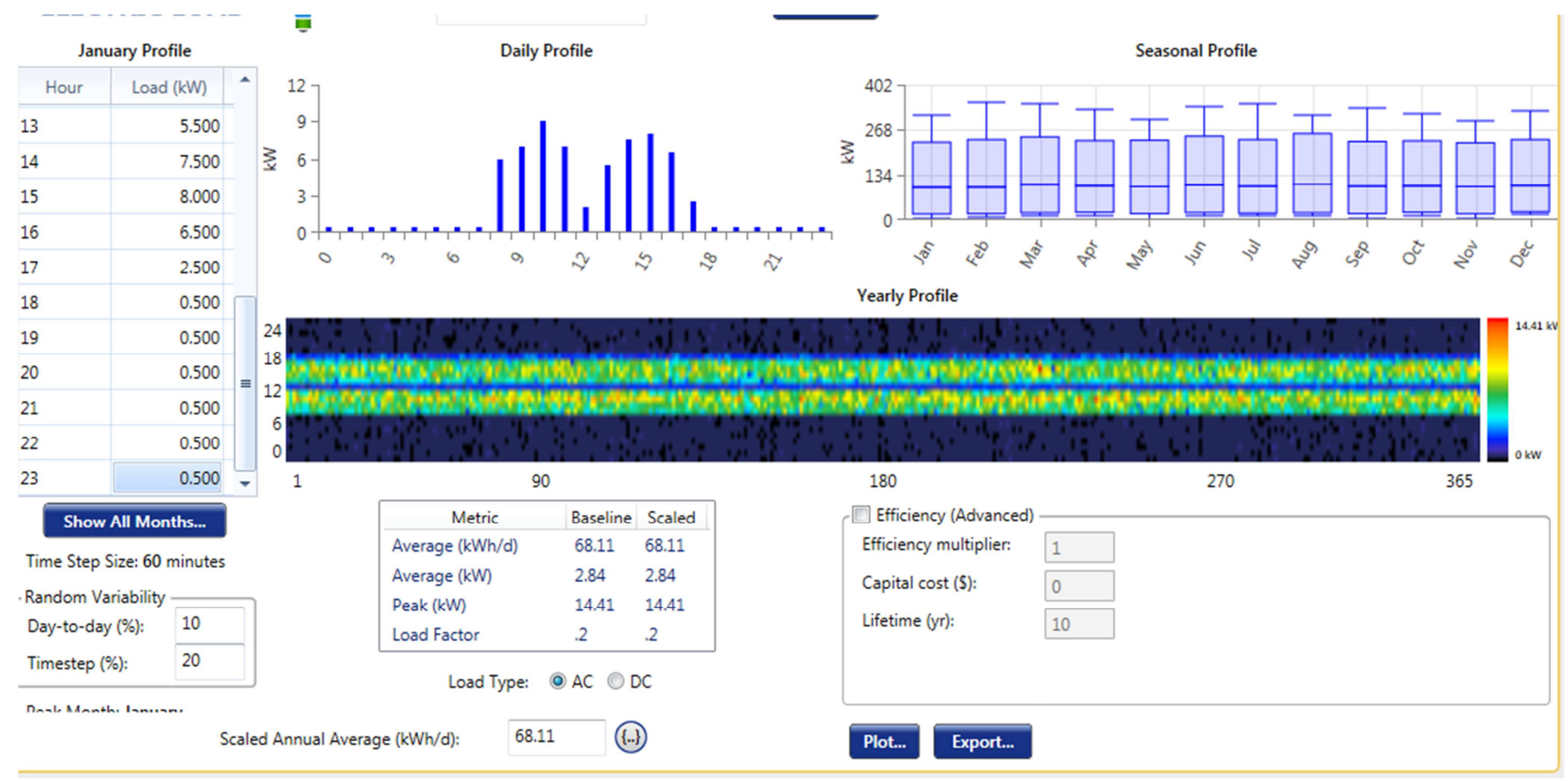

Figure 6. Daily power usage of KIOT and encode to HOMER software.

\section{Simulation Analysis}

The simulation process models the system configuration. It serves two purposes. First, it determines whether the system is feasible or not. HOMER considers the system to be feasible if it can adequately serve the electric loads and satisfy any other constraints imposed by the user. Second, it estimates the lifecycle cost of the system, which is the total cost of installing and operating the system over its lifetime. The quantity to represent the life-cycle cost of the system is the total net present cost (NPC). This single value includes all costs and revenues that occur within the project lifetime, with future cash flows discounted to the present. The total net present cost includes the initial capital cost of the system components, the cost of any component replacements that occur within the project lifetime, the cost of maintenance and fuel.

Table 5 below is generated based on the set of input values of the system configuration. The costs, capacity, quantity and lifespan of each component of the system are taken from the different websites. The diesel price is $0.75 \$ / \mathrm{L}$ and it is the current price of diesel in the country. Figure 7 shows the complete configuration of the system. It is composed of the PV panel, generating unit, batteries, converters, electrical loads and the $\mathrm{AC}$ and DC bus bars. 
Table 5. Inputs of data used for homer software simulation.

\begin{tabular}{lllll}
\hline Considerations & PV & Diesel generator & Battery & Converter \\
\hline Size $(\mathrm{KW})$ & 18.9 & 1 & $6594 \mathrm{AH}$ & \\
Capital $(\$)$ & $600 / \mathrm{KW}$ & $200 / \mathrm{KW}$ & 345 & 200 \\
Replacement cost $(\$)$ & $400 / \mathrm{KW}$ & $150 / \mathrm{KW}$ & 300 & 200 \\
Op \& ma cost $(\$ / \mathrm{yr})$ & 0 & 0.6 & 60 & \\
Sizes considered $(\mathrm{KW})$ & $0,18.9$ & $0,5,10,15,25,40,50$ & $0,1,2,3,4,5,6,7$ \\
Quantities considered & & & $5453 \mathrm{KWh}$ \\
Life time & 25 years & $30660 \mathrm{hrs}$ & $10,25,30$ \\
\hline
\end{tabular}

\subsection{Hybrid PV-Diesel System Optimizations Analysis}

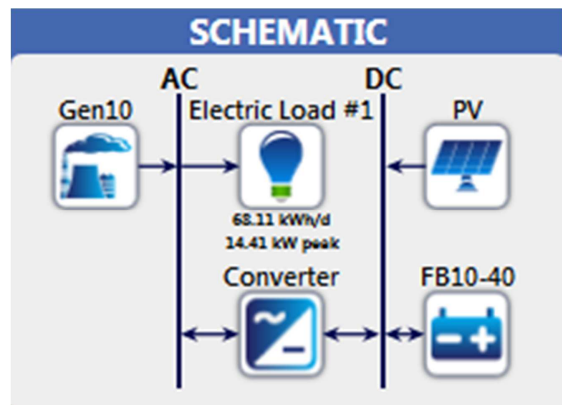

Figure 7. HOMER hybrid combination of PV and diesel with battery and converter.

The optimization process determines the best possible system configuration. In HOMER, the best possible, or optimal, system configuration is the one that satisfies the user-specified constraints at the lowest total net present cost. Finding the optimal system configuration may involve deciding on the standalone of components that the system should contain, the size or quantity of each component, and the dispatch strategy the system should use. In the optimization process, HOMER simulates many different system configurations, discards the infeasible ones, ranks the feasible ones according to total net present cost, and presents the feasible one with the lowest total net present cost as the optimal system configuration.

The optimization results are generated in either of two forms; an overall form in which the top-ranked system configurations are listed according to their net present cost (NPC) and in a categorized form where only the least-cost system configuration is considered for each system.

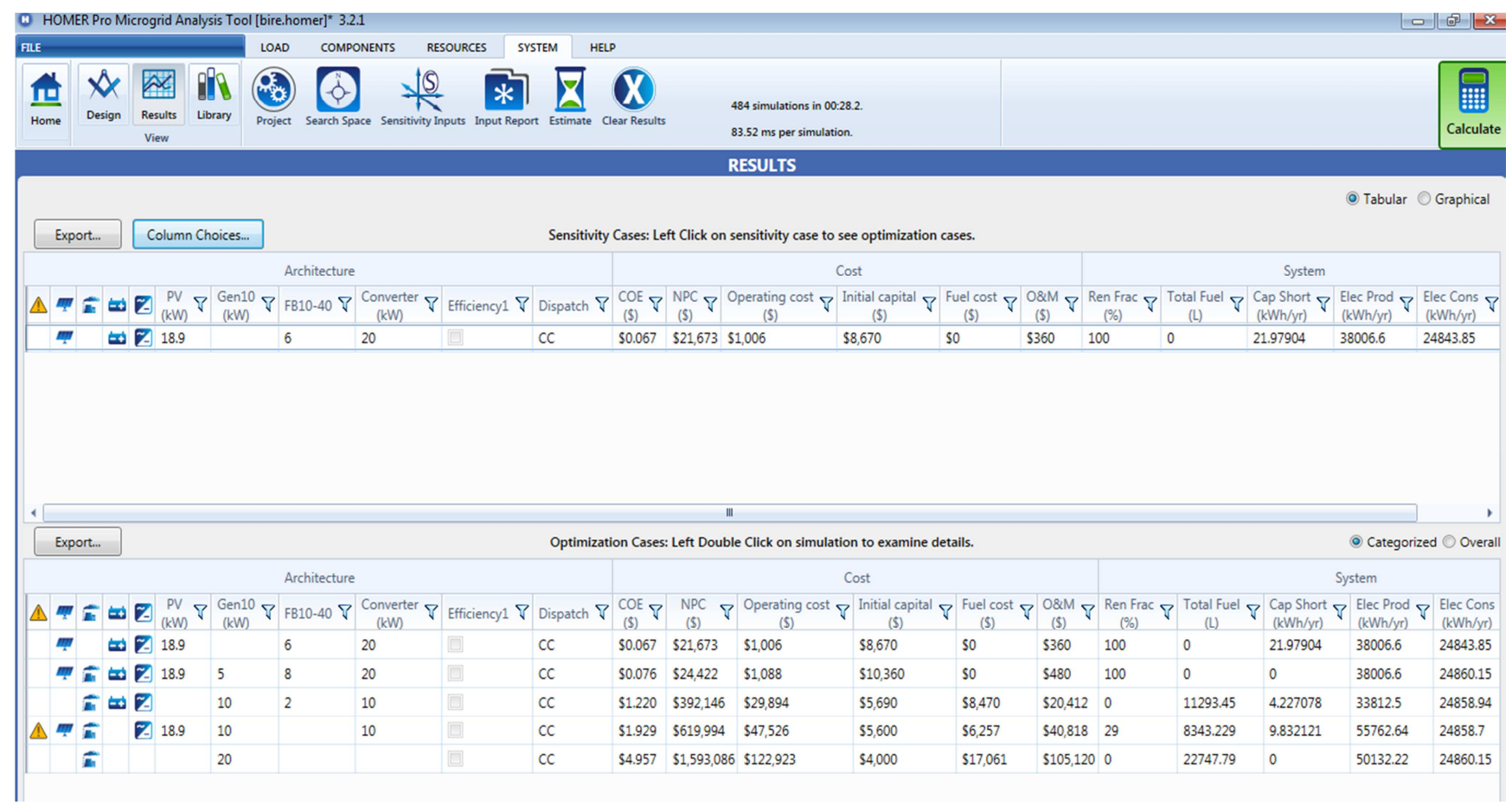

Figure 8. Hybrid system supply optimizations analysis.

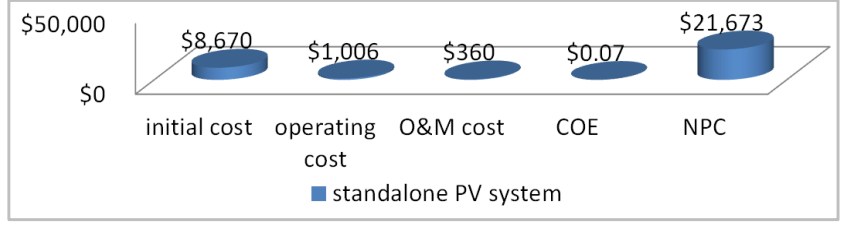

Figure 9. HOMER output of standalone PV system.

\subsection{Standalone PV System}

The result shows when we use PV system consider as standalone, so the graphs tell about different cost relation of over all the system. Currently, PV cell have high initial cost due to the it increase the total cost of the system, but PV has less O\&M, COE and relatively low operating cost. 


\subsection{Hybrid PV-diesel System}

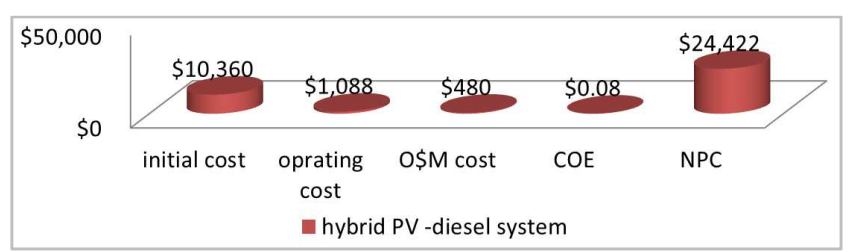

Figure 10. HOMER output of Hybrid PV and diesel system cost comparison.

Above figure shows the cost benefit of hybrid system, the cost of each type increases as comparison of standalone but more reliable. Now a day the cost of diesel varies and it affects the customers.

\subsection{PV, Diesel and Inverter System (Without Batteries)}

Inverter use to control the system of voltage, current and frequency of electrical power system also used to convert DC system to AC since PV system generate DC. The total cost of the result shows higher than both cases (case $1 \&$ case 2 ) due to the cost of inverter, diesel and fuel.

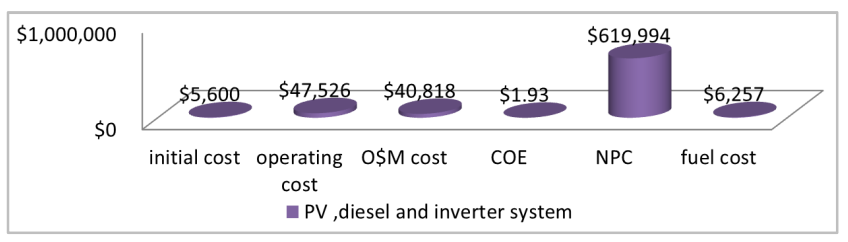

Figure 11. Simulation output of $P V$, diesel and inverter.

\subsection{Diesel Generator Analysis}

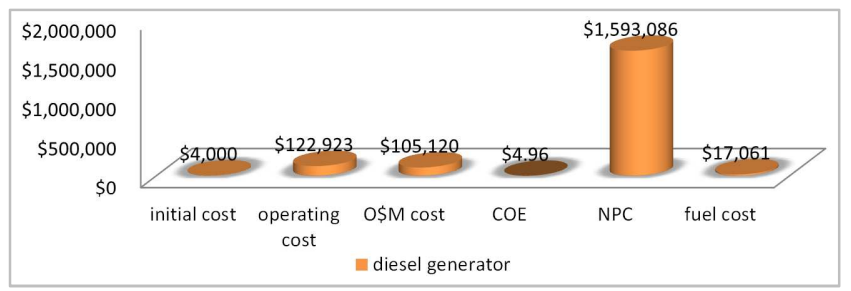

Figure 12. Simulation output only considering diesel generator.

Diesel generator even no need inverter it is still too costly in operating and maintenance (O\&M), so, that NPC is high as comparison of the among results.

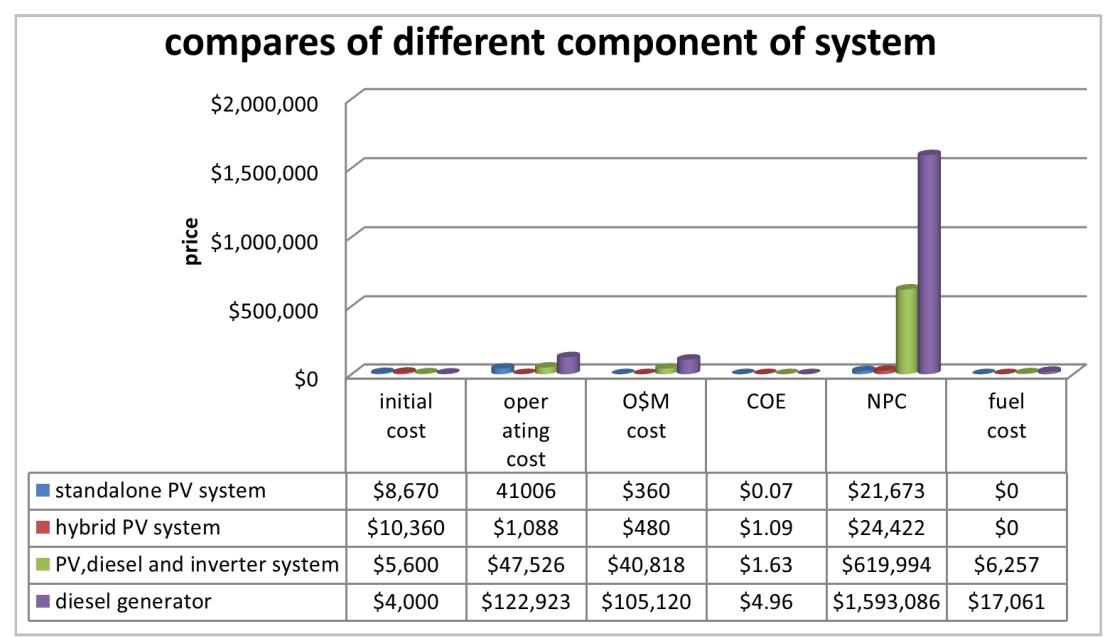

Figure 13. Graphical result of different component of system.

The above result shows that overall configuration of most cost effective system, i.e. the system with the lowest Net Present Cost, standalone PV-battery-converter set-up.

For this set-up, the total net present cost (NPC) is $\$ 21673$, the cost of energy (COE) is $\$ 0.067 / \mathrm{kWh}$, and contribution from renewable resources is $100 \%$. This setup could be a best solution and choice for implementation.

\section{Conclusion}

A standalone system comprising of PV arrays and diesel generator with battery banks and power conditioning units has been discussed in this study to achieve a cost effective system configuration, which is to supply KIOT administration building. The purpose is to have a continuous supply of electricity even during brown-outs. Before the design of the standalone PV system was started, and solar energy resources of the area under study were taken. Then, based on these resources, a standalone PV electric power supply system was designed.

The proponents therefore conclude that the design of this study is feasible to supply the entire load and at same time having the most economical cost from construction up to its lifetime. Therefore standalone PV system is more feasible than other different components of system and hybrid system (PV, diesel, battery and inverters) are more reliable than different components of system.

\section{References}

[1] Bimrew Tamirat, Comparative Analysis of Feasibility of Solar PV, Wind and Micro Hydro power Generation for Rural Electrification in the Selected Sites of Ethiopia.

[2] N. Razak, M. Othman, "Optimal sizing and operational strategy of hybrid renewable energy system using HOMER", IEEE transaction, pp. 495 - 501, June 2010. 
[3] A. T. D. Perera, R. A. Attalage, K. K. C. K. Perera and V. P. C. Dassanayake, "Designing standalone hybrid energy systems minimizing initial investment, life cycle cost and pollutant emission", Energy, 2013.

[4] S. M. Hakimi and S. M. Moghaddas-Tafreshi, "Optimal sizing of a stand-alone hybrid power system via particle swarm optimization for Kahnouj area in south-east of Iran", Renewable Energy.

[5] G. Bekele and G. Tadesse, "Feasibility study of small Hydro/PV/Wind hybrid system for off-grid rural electrification in Ethiopia”, Applied Energy, 2011.

[6] Farret, F. A. and Simoes, M. G. (2006) Integration of Alternative Energy Sources of Energy. John Wiley \& Sons, Hoboken.

[7] DOE's Office of Energy Efficiency and Renewable Energy (2004) Solar Energy Technologies Program Multi-Year Technical Plan 2003-2007.

[8] Keyhani, A., Marwal, M. N. and Dai, M. (2010) Integration of Green and Renewable Energy in Electric Power Systems. John Wiley and Sons, Hoboken.
[9] http://rredc.nrel.gov/solar

[10] H. Bai, C. Mai, "The impact of bidirectional DC-DC converter on the inverter operation and battery current in hybrid electric vehicles", Power Electronics and ECCE Asia (ICPE \& ECCE), 2011 IEEE 8th International Conference on May 2011.

[11] Steeby, Donald L. Alternative Energy: Sources and Systems. The Green Destination Series. Clifton Park NY, USA: Delmar Cengage Learning. $1^{\text {st }}$ Edition; 2012.

[12] Hart, Daniel W. Introduction to Power Electronics. Prentice Hall. 1st Edition; 1996.

[13] Morra, James. "Multi-Input Power Converter Will Upgrade Renewable Energy Networks.” Electronic Design. Online. Published 10 June 2015.

[14] PV Battery: Photovoltaic System Component. Solar Direct 2018.

[15] Rashid, Muhammad H. Power Electronics: Circuits, Devices, and Applications. Upper Saddle River NJ, USA: Pearson Educational Press. 4th Edition; 2014.

[16] F. A. Farret and M. G. Simões, Integration of alternative sources of energy, John Wiley \& Sons, New Jersey (2006). 